\title{
The Concept of Jihad In Islam
}

\author{
Ramlan \\ TengkuErwinsyahbana \\ Nurul Hakim
}

\begin{abstract}
It is an undisputable fact that jihad is an Islamic teaching that is explicitly mentioned in Quran, Hadith, ijma'as well as various fiqh literature from classical time to the contemporary time. Jihad term often used for things that are destructive by western scholars and society. For them, jihad is synonymous with terrorism. The similarization of the word Jihad with the word terrorism in the Western perception is strongly reinforced by a series of terror committed by Muslims in the name of jihad. These acts have been increasingly affecting the interpretation of the word jihad in a negative way although in reality that is not the case in a contemporary context. Jihad in contemporary understanding is not just a war against visible enemies but also a war against the devil and carnality. Even a war against visible enemies that are written in classical fiqh books has now replaced by a contemporary interpretation of jihad against the enemies, as was done by Dr. ZakirNaik.
\end{abstract}

KEYWORDS:Concept, Jihad and Islam

\section{INTRODUCTION}

When the 9/11 attack hit the United States more than a decade ago, the term jihad became a trending topic worldwide. The US and other Western countries in general claim that the perpetrators of the 9/11 attack were following the doctrine of Jihad in Islam in order to fight against America and its allies around the world. Since that time the doctrine of jihad serves as a common enemy to be fought with terror by America and its allies against some Islamic countries that are allegedly harboring terrorists.Nowadays, there are two poles of thought that see jihad from two very different points of views. The first is the terrorists' who interpret jihad terminology textually without looking at the context so that the classic concept of jihad as interpreted by the juries long time ago still used today. Secondly, the opinion of those who consider jihad as something that would endanger human life and needs to be eradicated from the roots. With this opinion, Western oppressors tried to eradicate Muslim countries in the name of terrorist control without no further detailed explanation sought.It is Interesting to study deeper how the actual concept of jihad in the perspective of both classical and contemporary Islamic fiqh interpretation. It is also interesting to explore some legal basis of the jihad concept emergence in Islam.

\section{JIHAD IN ETYMOLOGICAL AND TERMINOLOGICAL TERMS}

The concept of jihad can be viewed from linguistic and theological views. The meaning of the concept of jihad in Islamic law is made based on the Koran and the hadith. Etymologically, the word jihad is derived from the Arabic, the second form of isimmasdar of jaahada, yujaahidu, mujaahadatan and hihaadan which means "Work wholeheartedly". (Mansur, 1992: 9). Another meaning of the word jaahada is sincerity or great effort. (Ghafur. 2005: 183). Al Munjid fi lughahwa al-'Alam dictionary further mentioned the word jahadaaladuwwa, meaning qatalahumuhamatan 'aniddin which means "Attacking the enemy in order to defend the religion." (Ma'luf, 1986: 106). According to Ibn 'Arafah, al-jahd is interpreted as "to exert a full effort", whereas al-Juhd is interpreted as al-Mubalaghahwa al ghayah / redundant and aiming. (Romli and Sjadzili, 2004: 3).

Munawwir said, etymologically the word jihad derived from the word jahada, meaning power or abilities, while the word jihad means struggle. (Munawwir, 1984: 234). Manzhur in Lisan al-Arab stated that jihad is to fight the enemy, to devote all the ability and energy in the form of words, deeds or anything, someone could. (Manzur, t.th .: 198). IbnFaris in his book al-MaqayisMu'jam fi al-lughah, as quoted by QuraishShihab, stated that all words consisting of letters jim, ha and dal initially imply difficulty, hardship or those with similar meanings. (Shihab, 2005: 501). According to al-Raghib al-Ashfahani as quoted by Rohimin, the word al-jihad and mujahadah mean devoting capability in facing the enemies. (Rohimin, 2006: 17).

In Arabic, the term jihad etymologically is "devoting all ability and efforts". This is if the word jihad is taken from the word al-juhdu, but if the word jihad comes from the basic word of al-jahdu, it means "doing the job superfluously". (Zuhaili, 2011: 25). These words, however, contain three derivatives whose meanings are 
often separated and seemed to have no connection to each other. Those three words are jihad itself, mujahadah, and ijtihad. (Ghafur, 2005: 183). Jihad misunderstood as "using the muscles earnestly". So, it often defines as a physical war. Mujahadah interpreted as "earnest in the soul". This meaning is often used by the Sufis in the processes they go through in their lives purifications while ijtihad defined as "earnestly maximizing the mind in establishing a law".Terminologically, there are many definitions of jihad that are different from each other, sometimes. Sabiq said that jihad is making the fullest efforts, going to greatest lengths, and enduring all the difficulties in the fight against the enemies to resist aggressions, which by definition is now known as al-harb (war), which means an armed battle between two or more countries. (Sabiq, 1987: 50).

According to Shafi'iyah scholars, jihad is fighting the infidels for the purpose of glorifying Islam (Zuhaili, 2011: 6). Muhammad Ismail in BungaRampaiPemikiran Islam (the Anthology of Islamic Thoughts) mentioned that jihad is the effort to do all the ability to make war in Allah's way, either by involving directly or by assisting in the financial sector, expressing opinions (of jihad), or uplifting the spirits. According to him, the understanding of jihad is closely related to terms of war or such affairs. (Ismail, 1998: 117).

Lexically, jihad means devoting the fullest efforts and ability to get through difficult and serious problems. In this case, the jihad also means delivering the right advice before tyrants. (Nur, 2010: 27). According to Zuhaili, the definition of jihad that is in line with the Shari'a law is devoting all the capabilities and efforts to fight the infidels and to defend ourselves (against them), either with life, property or oral account. (Zuhaili, 2011: 26).SeyyedHusen Nasr said that the basic meaning of jihad is the exertion of effort, and only a small proportion of jihad refers to affairs of "war". In this case, jihad means fighting in the way of Allah against the forces of evil with life and property to triumph God's way in the face of the earth and definitely not fighting for worldly purposes. (Afahani, t. th .: 45-46). Yusuf Qardhawi divided jihad into three levels. First, jihad against the visible enemies. Second, jihad against Satan's temptation and third, jihad against worldly lust. (Qaradawi, 2010: 3).According to Sutan, commands on jihad in the form of war is very limited. As in times of peace, jihad means establishing, enforcing and composing. So jihad in times of peace is actually the great jihad because this type of jihad is willed the strength of brain power, the sincerity of sacrifice of treasures and objects in educating the community. (Mansur, 1982: 9).Because the meaning of jihad in Islam is very extensive and monolithic, jihad can be interpreted as an attempt of improvement that is fully deployed by someone. Therefore, inviting someone to the right path with a sincerity and gentleness is jihad. Making improvements in the areas of education and culture is jihad. Doing the repair or improvement of the economic and social level is jihad. Doing good deeds to parents, children, and wife is jihad. Giving attention to the social life of the community is jihad. Inviting people to the righteousness and forbidding them from digressions is jihad. Treating the non-Muslims who do not fight Muslims is jihad. Even doing good and behaving gently to the animals, plants and natural things is jihad. (Arake, 2012: 191).According to Habib Rizieq, jihad in the sense of syar $i$ has a general and specific meaning. The general meaning is to devote ability and sincerity in obedience to Allah. In this sense, jihad has a broad and common scope encompassing worldly passions jihad, political jihad, verbal jihad, worshipping jihad, knowledge jihad, propaganda jihad, and so forth. Specific Jihad is a holy war in the way of Allah, as referred to in the Koran verses that talk about jihad. As for the notion of shar'i (Shari'a), jurists define jihad as an effort to mobilize all forces in the war of fi sabilillah, either directly or by providing financial assistance, opinions, or logistics propagations, and other means (to win the battle). Therefore, the war in order to elevate the word of Allah is called jihad. (Saidurrahman, 2012: 57).

Hasan al-Bana, as quoted by Muhammad Chirzin, said that jihad is a Muslim obligation that continues until the end of time. The lowest level of jihad is the rejection of hearts on vices or digression and the highest level of jihad is the fighting in the way of Allah. Between them is a struggle with oral means, pen, and hands in the form of a statement of truth before a despotic ruler. (Chirzin, 1997: 12).

AzyumardiAzra gives the sense that jihad means a willingness to exert oneself earnestly. In English, it is referred to as "to exert oneself" which means making great efforts to achieve objectives that are consistent with the religious teachings, such as building a prosperity for mankind. Furthermore, Azra said that Jihad can be made in any way such as studying overseas or inside the country earnestly. People who seek knowledge are called those who strive in the path of Allah, jihad fi sabilillah. (Azra, 2000: 14).

Jihad is a unique, thorough activity, and cannot be equated with other religious activities. There is no religious practice performed without the component of jihad. At the very least, jihad is required to inhibit the worldly temptations and passions that always invite humans to the perfidy and neglect of religious persecution. The interpretation of jihad is often understood simply as a physical struggle / war. However, Based on the hadith of the Prophet when returning from the battle of Uhud, although physical warfare is also a form of jihad, but it is just a small part of the jihad itself. In addition, the meaning of jihad that is no less important is the jihad against the devil, and the jihad against the worldly passions for they are enemies of every human soul. (Shihab, 2001: 501-502, 506). 


\section{JIHAD IN THE SCRIPTURES OF THE KORAN AND THE HADITH}

In Islam, jihad is the top of religious teachings or fences that keep the fundamentals of religion, and also the protector of the Islamic nations and Muslims. Jihad is one of the most important basic teachings of Islam because jihad is a medium to achieve greatness, glory, and sovereignty. On that basis, jihad is compulsory and enforced until the Day of Judgment. Every nation that leaves the obligation of jihad would be insulted, and attacked by the enemies, their dignity would be humiliated by Allah and they will be controlled by despised and immoral people (Zuhaili, 2011: 26).Jihad is a rule that must be followed by Muslims. This is confirmed in alQur`an that specifically mentioned jihad as much as forty-one times in various tenses, (Ja'far, 2004: 311); 8 times in the Meccansurahs and 33 times in the Madaniyahsurahs (Baqi, t.tth. : 183) with the intention that jihad is a basic concept for Muslims in running their lives. As regards to the talks about the conception of jihad and an explanation of the substance of jihad as a religious teaching,it is written in 3 verses of 3 Meccansurahs and 24 verses in 13 Madaniyyahsurahs. The rest only used in other contexts that do not relate to the substance of jihad as Islam haq. However, systematically it is still used in the sense of jihad according to the etymological meaning which is "the earnestness in achieving the goals". (Rohimin, 2006: 16).

Based on the period of revelation, the term jihad rooted in the Qur'an are more revealed in Medina period than Mecca period. This fact suggests that in the Mecca period, the teaching of jihad has not been much responded by the Koran. Even at eight times of mentions, only four verses talk about jihad doctrine, the rest is used in other contexts. (Rohimin, 2006: 17) The amount of the mentions of the term jihad in the Medina period shows that the teaching of jihad in the Koran just got full responses after the Muslims were in a period of Medina, where the period is in accordance with the conditions of stronger and independent Muslims.

According to Muhammad Solikin, the word jihad with various modifications is mentioned 41 times in the Qur'an. Of the 41 times mentions, Solikin divided them into two groups. First, the mentioning of the level of words, contained in 5 verses, coupled with 1 verse with prefix and suffix. Those six verses refer to the jihad meanings: "The earnest attitude of living together with other believers" (QS. Al-Maidah verse 53), "sincerity in swearing by Allah" (QS. Al-An'am verse 109 and an-Nahl verse 38), "strengthening the oath to obey the Messenger" (QS. Al-Fatir verse 42), "the ability to do good individually" (QS. Al-Tawbah verse 79), "vow to fight the war, in certain circumstances "(QS. An-Nur verse 53). Of those five components, we can conclude that jihad is "earnestly implement the faith and obedience to Allah and His Messenger". (Sholikhin, 2009: 93).

Secondly, the mention of jihad with various forms of word, containing 9 meanings which are; courage and patience to face the test of Allah (QS. Ali Imran verse 142, and Muhammad verse 31), defending the prophet argumentatively from wrong public opinions (QS. Al-Mumtahanah 1), fighting for religion optimally with wealth and lives as evidence of faith (QS. Al-Nisa 'verse 95, Al-Tawbah verse 41, 44, 81, 86, 88. Al-Shaff verse 11 and Al-Hujurat verse 15), earnestly seeking the blessings of Allah (QS. Al-Tawbah verse 16. AlAnkabut verse 6 and 69), soothing yourself to the law based on the Koran (Qur'an, Al-Furqan verse 52), living in the path of Allah (QS. Al-Nisa 'verse 35, 54. Al-Tauba verse 19, 24 and al-Hajj verse 78), stabilization of the heart in tawhid as the process of hijra (QS. Al-Baqarah verse 218. Al-Anfal verse 72, 74, 75. Al-Tauba 20 and Al-Nahl verse 110), fighting against the disbelievers, polytheists, and hypocrites who openly fought the Muslims (QS. Al-Tawbah verse 73. Al-Tahrim verse 9) and lastly, going against other parties who coercively conduct coercion to associate Allah (QS. Al-Ankabut verse 8 and Lukman verse 15). (Sholikhin, 2009: 94-95).

Then, there is a big question coming; where exactly the fundamentalists (the term used by western scholars for extreme Muslims who hate the West) get the argument about the war as part of jihad? The text of verses of the Koran which talk about the theme of jihad, a religious war, shirk combat and law enforcement has always become a major theme for this fundamentalist groups. The Slogan "back to the Qur'an and Sunnah" and the shouts of "Allahu Akbar" always echoed in every movement and the mass demonstrations they title. Some verses about jihad and the war theme can be found in Allah's word in QS. Al-Baqarah [2]: 190, which means: "Fight in the way of Allah those who fight you but do not transgress. Indeed. Allah does not like transgressors".

This is the first verse revealed about war. According to al-Rabi 'and Anasr.a. (Al-Tabari, 2000: 561), this verse, which comes from the Medina period, is also the first war verses that will be found when opening the holy book of the Koran from the front. The verse text is clearly the command of Allah S.W.T. to fight the unbelievers who deliberately been doing evictions and fighting the believers. According to QuraishShihab, verse 190 of surah Al-Baqarah speaks about the time when it is permissible for Muslims to start the war. It can begin when and enemy/enemies attack. (Shihab, 2007: 126).

Many interpretations explaining the war verses like the one above is the response of the Muslims and their reactions to the arbitrary actions committed by the infidels. All historians agree that in the life of the Prophet Muhammad in Makkah, war was forbidden, and it is mirrored by many verses of the Koran from that period, which did not even talk about the war but rather emphasized a gentle approach. (Asa, 2000: 119). As the word of Allah S.W.T. in QS: Fushilat (41): 34, which means:

"And not equal are the good deed and the bad. Repel [evil] by that [deed] which is better, and thereupon the one whom between you and him is enmity [will become] as though he was a devoted friend". 
The majority of Muslims consider jihad as fardkifayah which is based on the proposition of the Qur'an and the hadiths of the Prophet. (Ismail, 1998: 111). The verses of the Qur'an that mention the importance of jihad among others, can be found in Al-Baqarah (2) verse 218, which means:

"Indeed, those who have believed and those who have emigrated and fought in the cause of Allah - those expect the mercy of Allah. And Allah is Forgiving and Merciful".

The verse above tells us that the true believers who remained in the faith and joined the prophet together in such emigration or joined the prophet in jihad to defend Islam, raised Kalimatullah, and fought the infidels with a vengeance, are worth expecting the grace and pleasure of Allah. (Maraghi, 1984: 257).

SuratAl-Baqarah (2) verse 244 states:

"And fight in the cause of Allah and know that Allah is Hearing and Knowing".

Fighting $f i$ sabilillah means fighting with the intention of elevating Kalimatullah, securing the preaching of Islam. The purpose is to make sure that its adherents are not disturbed and prevented from religion or religious instructions. In addition, the aim is also to defend the country from enemies' attacks that wanted to colonize the wealth and the independence. (Maraghi, 1984: 389).

It is undeniable that the "extreme" textual understanding of jihad nowadays is strongly influenced by the ideas of classical scholars, especially the classical interpreters, for example, the classic interpretation of Zamakhsyari. Nasikh-mansukh theory said that wars of the Prophet Muhammad's were wars against all infidels: "Because they are all against the Muslim community and intend to fight. So they are in a legal battle, whether they fight or not. "(Zamakhsyari, 2012: 231).

One of the most important thing to note is the number of erroneous interpretations of the Qur'anic verses themed jihad or war in Islam though the term jihad and war are two different words with two different meanings.

HamkaHaq said that there are verses that explicitly refer to a physical war with "qitaal", not "jihad", (Haq 2009: 202) as in verse of Al-Baqarah [2]: 190, which means:

"Fight in the way of Allah those who fight you but do not transgress. Indeed. Allah does not like transgressors".

Most scholars state that since the revelation of the verse above, for the first time the war is allowed by sharia law, because previously war is agreed to be an abomination in Islam (Qurtuby, 1372 H: 347) Thus, the Prophet was given permission to defend the people who fight against the Muslims ever since, but they should stop the war against those who were willing to live in peace. (Kathir, 1401: 227).

Thus, physical battles called al-qital can only be justified if it aims to defend and protect the safety and lives of many people. Usually, such war was forced to be taken as a last resort when people run into incredible chaos (fitna) that already threatens the security and peace so that God commanded to dampen the threat. (Haq 2009: 203). Others say the war al-qital is also part of jihad.

In Qital Jihad (war), there is the system adopted namely defensive and offensive jihad. Defensive jihad is done when the Muslims or their countries are attacked by infidels' people or countries such as Afghanistan and Iraq that are occupied by the United States until now and Palestine that is occupied by Israel. Offensive jihad is done through war. This is done when the Jihad Islamic propaganda carried out by the Islamic state are blocked by the infidels with their physical power. Da'wah(speech) is a non-physical act which should not be confronted with physical force. However, if that happens, Muslims are required to protect the da'wah and eliminate physical obstacles blocking it. (Iskandar, 2006: 32).

According to Abdurrahman Wahid, there are several kinds of jihad, namely:

a. Jihad in the sense of war (qital) that if we only fight in the way of Allah or we are attacked and fight otherwise if no war was eliminated

b. Jihad means to uphold the oneness of Allah, tawhid or anthologies, how Almighty God can be proven

c. Jihad must be able to prevent damage to those who have been protected by religion. (Wahid, 1982: 48).

While the hadiths that referenced the importance of jihad in Islam can be seen in the hadith narrated by Abu Hurairah whose validity agreed upon by al-Bukhari and Muslim as follows: Messenger of Allah asked," what is the most important deed? "He replied:" Faith in Allah and His Messenger ". Then, he was asked again, "Then what else?" The Prophet replied, "Jihad in the way of God" (H.R. Al-Bukhari and Muslim). (Bukhari, t. th.: 243).

Then the hadith narrated by Abu Sa'id al-Khudri whose validity is agreed upon by Bukhari and Muslim: "A man came to the Prophet. and said, "who is the best man? 'Messenger of Allah said," A believer who strive with their wealth and soul in the way of Allah ". The man asked again, "Then who else?" The Prophet replied, "A believer in Syi'ab (road in the hills; a kind of refugee camp), worshipping Allah and leaving the man from their crimes" (Reported by al-Bukhari and Muslim from Abu Sa'id al-Khudri). (Bukhari, t.th: 239).

\section{JIHAD IN CONTEMPORARY INTERPRETATION}

Jihad has become an important source of inspiration for Muslims for centuries. Nonetheless, in the latter half of the twentieth century, there is a "new" jihad globalization which is exploited internationally to

DOI: 10.9790/0837-2109073542 www.iosrjournals.org $\quad 38$ |Page


mobilize individuals and political and social movements, mainstream and extremist. (Esposito 2010: 126). Fundamental Islamic resistance against the West is increasingly intense, with many Islamic countries destroyed by West under the pretext of killing the terrorists. On the other hand, people who call themselves fundamental Islamist turns out to be enveloped by the spirit of jihad so that the struggle of the act is commonly to seek the pleasure of Allah SWT.

Jihad is sometimes referred to as the sixth pillar of Islam, even though there is no official explanation for that. The importance of jihad is rooted in the commands of Allah in the Koran to fight in the way of Allah and from the examples of the Prophet Muhammad's and his companions'. Throughout the history, the call for jihad has mobilized Muslims to defend Islam. Jihad is a concept that has diverse meanings. Jihad is used and abused throughout the Islamic history. (Esposito 2010: 85).

The Meanings of Jihad described by the Islamic scholars, mostly say ' to fight the infidels', then "to fight the lust, satan (devil), and evil". In the sphere of science, the definition of jihad can be etymological and terminological. In the practice of everyday life, all the definitions in the discussion of anything usually prioritize the terminological meanings (terms) compared to the etymological meaning (language). Ambiguity in interpreting the word jihad apparently has greatly impacted the livelihood of the world. The misinterpreted jihad meaning also makes Muslims increasingly cornered and threatened, as any Muslims are always considered to be jihadists or terrorists.

Efforts to correct the understanding of jihad has been done a lot by either the government or community organizations as MUI who issued a fatwa No. 3 of 2004 on the dangers of terrorism and the distinction between terrorism and jihad and confirmation of the prohibition of acts of suicide bombings carried out by terrorists in the name of jihad. Director of the Wahid Institute, ZannubaYenny Wahid, also called for streamlining the meaning of jihad, because today, jihad is only meant as a physical war. Whereas jihad in Islam is significantly more than that. Jihad of the Prophet Muhammad in Mecca period was not even physical. Furthermore, jihad with wealth (to help others, red) Is always called by Al-Qur'an as better than jihad with lives. (Aflahah, 2014: 83).

According to Ibn Abdullah Salih al-Fauzan, as cited by KasjimSalendra, there are five goals in the jihad:

1. Jihad against the worldly passions including self-control in running the commands of Allah and avoiding His prohibitions. Jihad against the passions is an uphill struggle (jihad akbar). Although this type of jihad is hard to do, but it is needed throughout the life.

2. Jihad against the devil who is the real enemy of mankind. Satan has the determination to always tease people and turning them to always rebel against Allah, staying away from all that has been commanded by God.

3. Jihad dealing with people who commit ungodly acts and those who deviate from among the faithful. In this jihad, the method used is commanding the good and forbidding the unjust. Jihad in this form requires a great patience and fortitude as well as adjustments to the capacity of the jihadist, and the condition of the object of da'wah. It is intended that the application of jihad is beneficial to people.

4. Jihad against the hypocrites, those who pretend to be Muslims and believers but their hearts are in fact still deny the oneness of Allah and the Prophecy of Muhammad. Facing the hypocrites are harder than the other jihad because they are very good at hiding their falsehood.

5. Jihad against the infidels. These models are often understood as jihad in war. (Salendra, 2009: 133-135).

Gamal al-Bana stated that the term jihad indicates a specific content that has a sense of a tool or a goal that can deliver someone to the destination. Jihad is not necessarily a war, although there is no doubt that there is also jihad in war. (Al-Bana, 2006: 22). SayyidQutb said that the point of departure of jihad in Islam is to proclaim Islam, to liberate humanity from disbelief, to place God's uluhiyah on earth, to destroy the Evil-thaghut that enslaves mankind, and to free mankind from the worship of one another and to worship Allah alone. (Qutb, 2003: 121).

The meaning of jihad is not only "struggling or fighting in a war" but can also be "trying an effort earnestly". Jihad fi sabilillah means to strive earnestly in the way of Allah, (Sudarto, 1999: 150), or in other words, there is no blessed jihad except the jihad in the path of Allah (QS. Al-Maidah [5]: 54, Al- Anfal [8]: 72, and At-Tawbah [9]: 41, 81), such as the fight against poverty and ignorance,the fight to improve the health status of the people, to build health care centers or hospitals, and to help street children. All this can be called a jihad fi sabilillah. However, the most popular jihad is jihad that has a narrow sense, namely physical struggle with the weapons. (Ma'munEfendiNur, 2010: 30).

Jihad is a total effort by a man that one of its forms is the sacrifice of treasures and lives with the intention to do so in the path of God to gain mercy, and forgiveness. (Shihab, 1991: 284). M. QuraishShihab considered that jihad with wealth and soul as the sacrifice jihad for this jihad needs wealth and soul sacrifices.

As for how to strive with wealth and live, it can be done by:

1. Jihad with wealth by:

a. Providing assistance to defend the faith.

b. Giving residence for people in need. 
c. Providing the cost of hijrah (leaving residence motivated by hostility towards the area). The current context could perhaps be interpreted as providing financial assistance to the seekers of religious knowledge.

d. Utilization of private properties for the sake of defending the truth of the teachings of Islam.

e. Loving Allah more than the property.

2. Jihad with the soul can be done by:

a. Directly involved in risking life by going to war in defense of religion.

b. Performing hijrah as stated above.

c. Increasing faith and renewing it from time to time.

d. Earnestly devoting what is held in the form of energy, thought, time in the way of Allah, keeping the words and deeds and remained on the teachings of Islam.

e. Loving Allah more than anyone in the family. (Ngadhimah and Huda, 2015: 3).

It should be remembered, however, that the jihad against the infidels and hypocrites in concept and application still exists, but not with violence as to carry out suicide bombings. M. QuraishShihab reiterated that jihad against the hypocrites is often mentioned in the series of verses about jihad in fighting the infidels (among others in the QS. Al-Tahrim [66]: 9, QS. Al-Tawbah [9]: 73). The mention of the hypocrites in the series of commands of jihad in fighting the infidels is a form of threat to thrill hypocrites that they can be equated with unbelievers who are permissible to be fought, killed and captured. (Ngadhimah and Huda, 2015: 11).

The way of Jihad by fighting the infidels and hypocrites can be done by:

1. Jihad to combat the infidels can be done by:

a. Unfollowing the desires of the unbelievers who associate Allah and oppose His Messenger.

b. Preaching, explaining the nature of the teachings of the Koran, highlighting its merits, dismissing excuses that are intended to weaken and displaying it in good examples.

c. Devoting all abilities to face the polytheists with sentences that can touch logic and heart, not with physical weapons to injure or to take lives.

d. If the interference and threats from unbelievers persist, then they must be fought.

e. Being firm on infidels who harass Islamic teachings and Muslims. The Assertion is realized with the efforts to defend Islam and its civilization by enriching oral and written works while explaining the teachings of Islam and countering the ideas opposed to it.

f. By not fearing the reproach of the infidels.

g. Undertaking measures adapted to the attitude and behavior of each of the polytheists, the greater the danger that may arise, the greater the sanctions provided, if necessary, murder is also allowed, but it is the last option and not an obligation that must be carried out as obligatory prayers and zakat.

2. Jihad against the hypocrites can be done by:

a. Telling the truth to hypocrites.

b. Trying in earnest with heart, oral, property, and life or any abilities possessed by each individual in accordance with the conditions and situations to improve their conditions so that they are truly and genuinely faithful, accompanied by efforts to avoid disruption and threat from them.

c. If interference and threats from hypocrites continue to come, while the hypocrites remain in their hypocrisies, the efforts to attract their hearts continue until their hearts are willing to accept the teachings of Islam

d. With tongues, hands, and at least with murky face against them, or can also be done by enforcing legal sanctions for their sins and transgressions. (Shihab, 2005: 332).

The Chairman of PW. Muhammadiyah North Sumatra 2005-2010 periodDalail Ahmad, MA, defines jihad as an activity that carries the image of Islam in an honored way, of course, with the way of peace, not in an harming way. Jihad makes Islam becoming more respectable in the eyes of other religions. With jihad, other religions will assess Islam as a true and should-be-followed religion, instead of hating Islam. The term jihad is often marred by acts which did not even have the value of jihad. Thus, conceptually, he stated that any act committed by Muslims that can honor the image of Islam is called jihad (Saidurrahman, 2012: 61).

Theologically, Islamic thinkers provide a different understanding of the concept of jihad. Its scope is very broad, ranging from the fight against the passions, taking up arms to battle until the sense of an effort in an earnest way for a good purpose. However, there are substances that can be justified in jihad; jihad is nucleated as an appeal to the religious right. Therefore, if jihad is associated with the word fi sabilillah, it means to struggle or to fight in the way of Allah, a struggle which can be done by hand or oral mean. (Marijan, 2003: 202-203).

According to AzyumardiAzra, the Islamic concept of jihad is understood merely as war activities as proposed by Western thinkers and Muslim thinkers themselves. It is not true. According to him, jihad literally means earnest, therefore those who are earnestly trying called "mujtahid". Jihad carried out in any field, for example, studying and teaching earnestly. Scientific activity is also referred to as jihad in Allah's way. Therefore, the notion of jihad according to Azra is very broad, ranging from seeking and teaching knowledge, earning a living, supporting a family, and so on. (Azra, 2000: 14). 
Tafsir al-Qur`an expert, Ar-Raghib al-Isfahani, in his Qur`anic dictionary, Mu jamMufradat Al-Fazh Al-Qur`an, asserted that jihad and mujahadah mean exerting every effort to defeat the enemy; and the enemy of a Muslim consists of three kinds, namely the real enemy in the form of human, unseen in the form of demons and lust. (Shihab, 2005: 506). The source of all evilness is Satan who often take advantage of the weakness of human passion. When a human is being tempted by Satan, he becomes an infidel, hypocrite and will be suffering from other spiritual diseases. Facing them would need all the potential that exists in humans' minds, hearts, and overall physics.

Jihad is a peaceful method to invite people to the religion. This has been done by previous prophets such as Abraham, Moses, and Jesus. Furthermore, all religions generally and effectively spread peacefully among humans with freedom. But when a handful of people are not satisfied with the rejection of peace and tend to try to combat the new religion, then it means they injure the rights and freedoms of others. (Arfa, 2008: 64).Jihad in the broad sense requires funding, mind, and energy. That is why the number of verses that mention jihad of treasures comes along with jihad of power. Jihad of treasure is a priority, the seriousness of the donation of property for the benefit of humans, followed by the physical jihad. Both physical and wealth jihad are intended as an effort towards the common good, as the ultimate goal of Islamic law. (Haq 2009: 202).

Jihad of possessions or physical jihad, let alone the jihad of live (war) is not the principal purpose of sharia. All of that is just the way that is sometimes taken to build a more prosperous life and dignity. Therefore, it is quite wrong if people flip logic at the expense of the soul and for the sake of making war as an instinct and basic objectives. (Haq 2009: 202). There are many universal values contained in jihad. Jihad in the sense of earnest effort creates the good of the environment, nature, and the world as a whole. Therefore, in this context, jihad means exert yourself to build prosperity for mankind, enforce national discipline, build a more democratic country, and more justice are the values of universal jihad, that could be applied to anyone, Muslim, and nonMuslims. (Azra, 2000: 15)

Educational activities can also be included as a jihad. Jihad in education and teaching meant here by HilmyBakarAlmascaty is the struggle to uphold the word of God by means of education and all its equipment. Education is defined as the process of transformation of knowledge completely and thoroughly, including the moral example of the educators. Thus, it is not only the provision of science alone, but it also involves all aspects required in order to establish committed Muslims to the teachings of Islam, insightful, and have a specific useful knowledge, both formally in educational institutions with curriculum composed detailed, and informally in science assemblies held to meet the needs of the Muslims. (Almascaty, 2001: 185).

\section{CONCLUSIONS}

There is actually nothing wrong with jihad meaning both etymologically and terminologically. The concept of jihad has nothing to be questioned about. it is only the human interpretation of the text that might be mistaken which even worse, is then implemented in the wrong form. Jihad as Islamic teaching may actually provide tremendous positive effects if it is put into action by Muslims.

The war that is believed by Westerners as the real form of the spirit of jihad, is just a few aspects of the meaning of jihad, which unfortunately is understood as a single meaning by Westerners. The impact of this is innocent Muslims become victims of Muslims textual interpretation errors about jihad plus a narrow understanding of the Westerners anyway. Though in reality, Islam through the Qur'an and the Hadith of the Prophet Muhammad, always teaches peace, compassion, and love, as a form of rahmatanlil-'alamin (blessing for univers).

\section{Books}

[1] Abdurrahman Wahid, 1982, MenelanCakrawala, Shalahuddin Press, Yogyakarta.

[2] Ahmad WarsonMunawwir, 1984, Kamus Arab-Indonesia, Yogyakarta, Al-Munawwir.

[3] Al-Tabari, 2000, Jami' al-Bayan fi Ta'wil al-Qur'an, Jilid III, Muassasah al-Risalah, Beirut, Cet. ke-2.

[4] AlwiShihab, 1999, Islam Inklusif: MenujuSikapTrebukadalamBeragama, Mizan, Bandung.

[5] Asfahani, Raghib al-, t.th., al-Mufradat li Gharib al-Qur'an, Daar al-'Ilmiyah, Beirut.

[6] AzyumardiAzra, 2000, Islam Substantif: Agar UmatTidakJadiBuih, Mizan, Bandung,.

[7] Bana, Gama al-, 2006, al-Jihad, penterjemah Tim Mata Air Publishing, Mata Air Publishing, Jakarta, 2006.

[8] Baqi, Muhammad Fuad 'Abdul, t.th., al-Mu'jam al-Mufahras li al-Faz al-Qur'an al-Karim, Dar Ihya alTuras al-'Arab, Beirut.

[9] Bukhari, Muhammad bin Ismail al-, t.th.,Shahih al-Bukhari, Juz. II, Dar al-Ihya al-Kitab al-'Arabiyah, Kairo, t.th.

[10] Esposito, John L., 2010, MasaDepan Islam AntaraTantanganKemajemukan Dan BenturanDengan Barat, penterjemah Eva Y, Nukmandan Edi Wahyu SM, Mizan, Bandung. 
[11] FaisarAnandaArfa, 2008, TeoriHukum Islam TentangHakAsasiManusia, Citapustaka Media, Bandung.

[12] HamkaHaq, 2009, Islam Rahman UntukBangsa, RMBOOKS, Jakarta.

[13] HilmyBakarAlmascaty, 2001, PanduanUntukAkrivisGerakan Jihad, GemaInsani Press, Jakarta.

[14] KacungMarijan, 2003, "TerorismedanPesantren", dalam Muhammad Asfar (ed)., Islam Lunak Islam Radikal : Pesantren, TerorismedanBom Bali, Pusdehamdan JP Press, Surabaya.

[15] KasjimSalendra,2009,JihaddanTerorismeDalamPerspektifHukumIslam, danLitbangdanDiklatDepartemen Agama RI.

[16] Katsir, Isma'il bin Umar Ibn, 1401 H, TafsirIbnKatsir, Juz I, Dar al-Fikr, Beirut.Ma'luf, Louis, 1986, alMunjid fi al-Lughahwa al-A'lam, Daar al-Masyriq, Beirut.Manzur, Manzur, t.th.,Lisan al-'Arab, Dar alMa'arif, Mesir.

[17] Maraghi, Ahmad Musthafa al-, 1984, Tafsir al-Maraghi, Jilid II, Toha Putra, Semarang.Moh. Guntur Romlidan A. FawaidSjadzili, 2004, Dari Jihad MenujuIjtihad, LSIP, Jakarta, Cet. I.

[18] Muhammad Chirzin, 1997, Jihad dalam al-Qur'an: TelaahNormatif, Historis, danProspejtif. PustakaPelajar, Yogyakarta.

[19] Muhammad Ismail, 1998, BungaRampaiPemikiran Islam, GemaInsani Press, Jakarta.MuhammadSholikihin, 2009, The Power Shabar, TigaSerangkai, Jakarta, 2009.

[20] Qardhawi, Yusuf, 2010, Fiqih Jihad SebuahKarya Monumental TerlengkapTentang Jihad Menurut alQur'an danSunnah, Mizan, Bandung.

[21] QuraishShihab, M, 2001, Wawasan al-Qur`an: TafsirMudhu`IatasPelbagaiPersoalanUmat, Bandung: Mizan.

[22] -------, 2005, Wawasan al-Quran: TafsirMaudu'iAtasPelbagaiPersoalanUmat, Vol. I., Mizan, Bandung.

[23] -------, 2005, Tafsir al-Mishbah: Pesan, KesandanKeserasian al-Qur'an, Vol. 14, LenteraHati, Jakarta.

[24] ------, 2007, Ayat-AyatFitna, LenteraHati, Tangerang.

[25] Qurtuby, Muhammad bin Ahmad bin AbiBakr bib Farh Abu Abdillah al-, 1372 H, Tafsir al-Qurtuby, Juz II, Dar al-Sya'b, Kairo.

[26] Qutb, Sayyid, 2003, Tafsir fi Zhilal al-Qur'an, penterjemahAs'adYasin, dkk, GemaInsani, Jakarta.

[27] Rohimin, 2006, Jihad: MaknadanHikmah, Eirlangga, Jakarta.Sabiq, Sayyid, 1987, FiqhSunnah, Jilid 11, PT Al-Ma'arif, Bandung.

[28] Sudarto, 1999, Konflik Islam Kristen, MenguakAkarMasalahKonflikAntarUmatBeragama di Indonesia. PustakaRizki Putra, Semarang, Cet. ke-1.

[29] Sutan Mansur, A.R.. 1982, Jihad, PanjiMasyarakat, Jakarta.Syu'bahAsa, 2000, TafsirAyatAyatSosialPolitik, GramediaPustaka, Jakarta.

[30] Waryono Abdul Ghafur. 2005, TafsirSosial, MendialogkanTeksdenganKonteks, Yogyakarta: elSAQ Press.

[31] Zamakhsyari, 2012. al-Kasysyaf, Jilid I, Dar al-Hadis, Kairo.Zuhaili, WahbahAz-, 2011, al-Fiqh alIslamywaAdillatuhu, Jilid 8, GemaInsani, Jakarta.

[32] Aflahah, "AnalisisSemiotikaMakna Jihad Dalam Film Sang KyaiKaryaRakoPrijanto", dalamJurnal OKARA, Vol. 2 Tahun IX., Nopember 2014.

[33] Arief B. Iskandar, "MendefinisikanKembaliMakna Jihad", dalam al-Wa'ie No. 65 Tahun VI, edisi 1-31 Januari 2006.

[34] HasbullahJa'far, "Konsep Jihad dalam al-Qur'an", dalamIstislahJurnalHukum Islam, Vol. III, 2 JuliDesember 2004

[35] LukmanArake, "PendekatanHukum Islam Terhadap Jihad danTerorisme", dalamUlumunaJurnalStudiKeislaman, Vol.16 Nomor 1 Juni 2012.

[36] Ma'munEfendiNur, "Hukum Jihad danTerorisme: Perspektif Al-Qur'an", dalamJurnalMaslahah, Vol. 1, No.1, Juli 2010.

[37] MambaulNgadhimahdanRidhol Huda, "Konsep Jihad Menurut M. QuraishShihabDalamtafsir AlMishbah Dan KaitannyaDenganMateriPendidikan Agama Islam", dalamJurnalCendekia, Vol. 13 No. 1, Januari-Juni 2015.

[38] Saidurrahman, "Fiqh Jihad danTerorisme (PerspektifTokohOrmas Islam Suamtera Utara)", dalamSyir'ahJurnalIImuSyariahdanHukum. Vol. 46 No. 1. Januari-Juni 2012. 